\title{
DAVID HUME E A CRÍTICA À NOÇÃO DE SUBSTÂNCIA
}

\author{
Caio Leone de Almeida Moura Filho'; Wagner Teles de Oliveira² \\ 1. Bolsista PIBIC/CNPq, Graduando em Filosofia, Universidade Estadual de Feira de Santana, e-mail: \\ leone.gnosesophia@gmail.com \\ 2. Orientador, Departamento de Ciências Humanas e Filosofia, Universidade Estadual de Feira de Santana, e-mail: \\ wtoliveira@uefs.br
}

PALAVRAS-CHAVE: Substância; Sujeito; Impressões e Ideias

\section{INTRODUÇÃO}

O princípio empirista segundo o qual toda ideia deriva de uma impressão correlata e a representa figura, na obra de Hume, como princípio que ordena a investigação, além de funcionar como critério segundo o qual decidimos a legitimidade das teorias. Aliás, é exatamente por funcionar como critério de legitimidade das teorias científicas, que o princípio empirista pode ordenar a investigação, sendo ele o responsável pela conversão operada pela obra de Hume da teoria em inquérito. Essa conversão significa que, agora, o empirismo possui como método de investigação a redução das ideias às suas impressões correspondentes, o que é o mesmo que dizer que a experiência ganha ares de tribunal da ciência. Afinal de contas, o expediente de aplicação do princípio empirista se resolve exatamente em fazer as ideias remontarem a sua origem. É verdade que, nesse caso, o princípio empirista atua em concurso com o atomismo, de modo que fazer ideias, complexas como tais, remontar à sua origem significa fazê-las remontar aos átomos da experiência a partir dos quais elas se constituíram. Em sendo assim, por um lado, a aplicação do princípio empirista consistiria na afirmação da origem simples das ideias; por outro, na afirmação incontornável de que as ideias são também efeito de princípios de associação que atuam no espírito humano. É claro que, tanto como a primeira, a última afirmação jamais representou qualquer dificuldade para o empirismo, mesmo no que respeita ao empirismo lockeano, na medida mesma em que as duas afirmações, tomadas em conjunto, não significam mais do que se por um lado as impressões de sensação são a origem do espírito, por outro, as impressões de reflexão não podem ser senão efeito dos princípios que atuam nesse mesmo espírito. Em outras palavras, é como se, nesse caso, Hume reiterasse que o sujeito se define pela atividade na mesma medida em que se define pela passividade. Ou seja, se a passividade que o define permite que $o$ compreendamos como mero receptáculo das ideias, isto, no entanto, não anula a sua atividade da qual aquelas mesmas ideias devem resultar. Nesse sentido, pode-se afirmar que são exatamente as impressões de reflexão que tornam possível qualificar o espírito humano como sujeito. Com efeito, se o princípio empirista situa os átomos da experiência como origem das ideias, os princípios de associação segundo os quais esse mesmo material empírico é operado por um sujeito são definidos exatamente pela capacidade de ultrapassar o dado. Por essa perspectiva, deve interessar ao empirismo humano, muito mais do que a origem do espírito, o problema da constituição do sujeito, mesmo porque aplicação do princípio empirista permitirá à filosofia humeana afirmar não encontrar qualquer impressão que possa corresponder à ideia de substância ou de eu. Desse modo, resta à filosofia humeana afirmar ser o sujeito constituído unicamente por uma coleção ou feixe de impressões. No entanto, a dificuldade é compreender como a identidade do eu, tão essencial à constituição do sujeito, pode ser afirmada sem uma substância a partir da qual seja possível discernir as propriedades acidentais das essenciais que, por ventura, pertençam ao sujeito. É justamente em virtude dessa dificuldade que a noção de substância sempre figurou na história da filosofia, como uma espécie de herança aristotélica, como condição primeira de toda predicação possível, mesmo em se tratando de uma filosofia de matiz cartesiana. Nessa medida, o trabalho do 
bolsista consistirá em analisar, a partir sobretudo da leitura da Investigação sobre o entendimento humano, como a filosofia humeana, depois de demolir a noção de substância é capaz de reconstituir uma subjetividade. À medida que envolve o tema da unidade do sujeito sem a qual não é possível sua constituição, a pesquisa do bolsista dialoga com o projeto "O Antipsicologismo e a Certeza em Wittgenstein", pois se aqui cumpre avaliar a perspectiva humeana segundo a qual o sujeito não é mais do que uma coleção de impressões, não sendo constituído por um núcleo essencial, em nosso projeto trata-se de examinar a relação determinação entre a proposição, enquanto ato de um sujeito, e a alma, a partir de uma crítica ao psicologismo que pretenderia fazer a significação lógica ser determinada por elementos anímicos.

\section{MATERIAL E MÉTODOS OU METODOLOGIA (ou equivalente)}

O método de pesquisa em filosofia consiste na leitura e escrita de textos segundo técnicas de exegese e de escrita que caracterizam a área. Assim, execução das atividades concernidas pelo plano de trabalho privilegiou o cotejo com as fontes primárias da pesquisa, sobretudo o Tratado da Natureza Humana, sem se furtar à apreciação de fontes secundárias, textos de destacados comentadores, que se inscrevem na tradição de leitura da obra de Hume, como, por exemplo, João Paulo Monteiro. Nesse sentido, o trabalho de pesquisa dividiu-se em duas etapas. Em uma primeira etapa, a da leitura, os textos indispensáveis à pesquisa foram cuidadosamente fichados. Em uma segunda etapa, a da escrita, uma vez vencida a etapa da leitura, foi elaborado um texto monográfico apresentado nas reuniões de nosso Grupo de Estudo e Pesquisa, de modo a permitir a apreciação dos resultados parciais da pesquisa por meio do debate das questões que ela envolve. A participação das reuniões semanais de nosso Grupo constitui um importante componente do método, pois permitiu ao bolsista, além de familiarizar-se com expedientes que são característicos da pesquisa na área, apresentar sistematicamente os resultados de sua pesquisa, perfazendo assim as condições para alcançar os resultados específicos do trabalho em filosofia.

\section{RESULTADOS E/OU DISCUSSÃO (ou Análise e discussão dos resultados)}

Nossa pesquisa consistiu na análise da obra de Hume, concentrando-se mais especificamente na crítica humeana à noção de substância. De acordo com a presente obra de Hume, as Investigações, nossos conhecimentos são limitados e nossas expectativas sobre o futuro dependem das nossas experiências passadas. Nossas percepções tem um papel fundamental e podemos compreendê-las como constituindo dois gêneros distintos: impressões e ideias. As ideias são percepções mais fracas e menos vivas do que as impressões. Qualquer pessoa sabe a diferença entre sentir e pensar. As ideias são cópias das impressões, imagens das nossas experiências. Ideias e impressões são classificadas em simples e complexas. Enquanto que as percepções simples não aceitam separação de seus elementos, como, por exemplo, a ideia de átomo, as percepções complexas podem ser divididas e reduzidas em elementos primários, pois representam percepções com determinada força e exatidão. Assim, nossas relações possuem duas fontes de percepções correspondentes, a saber, a experiência e o entendimento. Aquelas ideias que são frutos do nosso entendimento, ou das operações da nossa mente, como é o caso das matemáticas, não podem ser derivadas de outra fonte, pois ideias e impressões complexas possuem dois objetos da razão no entendimento, questões de fatos (questões de hábito e crença) e relações de ideias. Logo, não podemos dizer que a ideia de substância é derivada de nenhuma dessas fontes, pois a mesma não depende necessariamente de nenhuma impressão exata, tratando-se, apenas, de uma questão subjetiva que não corresponde a nenhuma percepção fixa existente em nosso entendimento. Tudo que há é um feixe de percepções: impressões e ideias. 


\section{CONSIDERAÇÕES FINAIS (ou Conclusão)}

Nossa pesquisa examinou a crítica de David Hume à noção de substância apresentada nas Investigações sobre o entendimento humano. Tendo em vista o lugar ocupado pela crítica presente na obra e na maneira como as questões foram formuladas e respondidas pelo autor foi possível reconstituir as exigências conceituais à luz das quais Hume faz ver que a ideia de substância não pode ser existente, dado que a ausência de percepções originárias determina a inexatidão e a inexistência de uma suposta noção da ideia de substância em nosso entendimento. Por esta razão, o sujeito nada mais é do que uma coleção de imagens, sensações, reflexões. A ideia de "eu" não existe, o sujeito é aquele que sente, ouve, ver, fala, ama, odeia, deseja. Isto é, se constitui a partir das percepções existentes de fato na experiência. Assim, Hume anulou de uma vez por todas a ideia de substancia da história da filosofia, mostrando o lado mais radical da teoria do conhecimento empirista do século XVIII.

\section{REFERENCIAS}

COVENTRY, Angela M. Compreender Hume. Tradução de Hélio Magri Filho. 2. ed. Rio de Janeiro: Vozes, 2011. (Série Compreender).

DELEUZE, Gilles. Empirismo e subjetividade: ensaio sobre a natureza humana segundo Hume. Tradução de Luiz Orlandi. 2. ed. São Paulo: Ed. 34, 2012. (Coleção TRANS).

HUME, David. Investigações sobre o entendimento humano e sobre os princípios da moral. Tradução de José Oscar de Almeida Marques. São Paulo: Ed. Unesp, 2004.

. Resumo de um Tratado da natureza humana. Tradução de Rachel Gutiérrez e José Sotero Caio. Ed. bilíngue. Porto Alegre: Edições Paraula, ed. Bilíngüe, 1995.

. Tratado da natureza humana. Tradução de Débora Danowski. 2. ed. São

Paulo, Ed. Unesp, 2009.

MARCONDES, Danilo. Iniciação à história da filosofia: dos pré-socráticos à Wittgenstein. $2^{a}$ ed. Rio de Janeiro: Zahar, 2007.

MONTEIRO, João Paulo. Hume e a epistemologia. São Paulo: Editora Unesp; Discurso Editorial, 2009. 